\section{Science for export}

\section{By Steven Edelson, Executive Editor}

Although every major university or institute would like to be located in a biotech hub and keep its discoveries close to home, only a few true hubs exist. For everyone else, the question is whether their research goes elsewhere to be commercialized. In the long run, the answer is usually yes. Much of the technology that is licensed to existing companies goes elsewhere. And although some institutions may form startups close to home, these often end up leaving once they need venture funding.

The lack of nearby corporate infrastructure also has more subtle effects on translational work at universities not located near major hubs. For example, researchers may not realize the commercial potential of their own work. As a result, many technology licensing officers at these institutions spend time training researchers to recognize the translational potential of their work, as well as ferreting out interesting discoveries within their own institutions, instead of devoting their resources to finding the best way to market those discoveries to VCs or potential partners.

Moreover, a common theme is voiced by universities in today's cash-constrained environment: licensing deals are harder to come by, as biotech and pharma companies are more reluctant to take on discovery-stage and preclinical projects.

The result is a greater emphasis on university spinouts, a situation in which institutions embedded in biotech hubs again have an advantage due to the concentration of management, financial, legal and technical skills.

"When times are tight and companies don't want to take on new commitments, it pushes you towards more startups. If you can't find a licensee, make one," said Ashley Stevens, executive director of the Office of Technology Transfer at Boston University and president-elect of The Association of University Technology Managers (AUTM).

The experience of the Massachusetts Institute of Technologyone of the universities most successful at commercializing technology-contrasts with the experience of institutions in five other regions: Chicago, Atlanta, Oxford in the U.K., France and Germany.

\section{MIT: setting the bar high}

MIT does about 100 deals per year, of which about $35-40 \%$ are in the life sciences, according to Lita Nelsen, director of the university's technology licensing department. Of the 100 deals, about 20 are start- ups, which translates to about 7 or 8 new biotech or device companies per year.

The remaining 80 deals include a small number of licenses to large companies and a large number of follow-on licenses, such as an improved version of a technology that has already been partnered with industry.

Only about $25 \%$ of MIT deals go outside the region.

"We end up doing the vast majority of our licenses and spinouts in the eastern half of Massachusetts," noted Nelsen.

This is possible because there is ample venture money and plenty of companies in New England. Since the start of 2005, the region's biotech companies have raised a total of $\$ 851.2$ million in announced series $\mathrm{A}$ financings, as tracked by BioCentury.

There have been 54 such deals, for an average round of $\$ 15.8$ million. That compares with the overall average of $\$ 15$ million for $\mathrm{A}$ rounds globally in the same time period. The global figure excludes a pair of outlier A rounds-a $\$ 300$ million financing by Ikaria Holdings Inc. and a $\$ 170$ million financing by Xanodyne Pharmaceuticals Inc. Including those deals, the global average is $\$ 16.2$ million.

However, even New England has not been immune to the economic downturn. There have only been two series A rounds in the region since March this year, and neither broke the $\$ 10$ million mark.

The dearth of dollars for new company formation is especially critical, given what Nelsen said has been increasing reluctance on the part of biotech and pharma companies to in-license university discoveries.

"For really innovative stuff-finding a drug for a particular disease or a really radical new way of making a biomedical device that's still very early and unproven - those tend not to be licensed, at least initially, to large companies," said Nelsen. "The reason is you can't get into them because they have their own agendas-their R\&D dance card is full."

Instead, Nelsen told SciBX, these discoveries go into startups with university faculty as founders. "This happens when the faculty knows, or the technology licensing office knows, how to get started. People have been spinning companies out of MIT for half a century," she said.

Indeed, said Nelsen, "we have an enterprise forum and a venture mentoring service. These kinds of entrepreneurial ecosystems are based at MIT but have active participation from the business community. Everybody knows everybody. A professor with an idea might come to us at the technology licensing office, but more likely he'll be at dinner with another professor who will tell him what to do."

The upshot, concluded Nelsen, is that "we have an unusual environment. I wouldn't know how to transplant it."

Stevens agreed that the close proximity to companies and VCs enjoyed by Boston-area institutions is very hard to duplicate. "The secret to somewhere like the greater Boston area is that it's much 
smaller than Chicago or Los Angeles or New York. Thus, it's a lot easier to network, and much of translational research is making the right connection," he said. "Despite partnering websites, it's still a humanto-human interaction."

Stevens does think there are general lessons that can be drawn from the biotech cluster in the Boston area. "You shouldn't change a university's culture, but we've found that you can quite definitely add a culture," such as establishing a mentoring program in which industry leaders work with faculty, he said.

\section{Chicago: caught in the middle}

Compared with MIT, the pace of spinouts and licensing in the U.S. Midwest is an order of magnitude lower. Northwestern University, for example, has spun out 13 new biotech and device companies in the past 5 years, according to Indrani Mukharji, executive director of technology transfer at the university.

The university's two most recently disclosed biotech spinouts are cancer screening company American BioOptics LLC and Viamet Pharmaceuticals Inc., which develops metalloenzyme inhibitors for infectious diseases and cancer (see Table 1, “Getting started").

Viamet was founded in 2005 and has raised $\$ 6.3$ million in a series A round. Although Viamet is based in Durham, N.C., American BioOptics remains close to Northwestern's campus. The company was founded in 2006 and is based in Evanston, Ill. Its money has come from grants, which it said has passed \$16 million.

Indeed, venture financing is less available for companies based in the Midwest compared with New England. Since January 2005, 24 biotechs in the Midwest have raised a total of
"The intellectual capital at a relatively isolated institution is not sitting in a bath of people thinking about translational relevance."

-Alan Thomas,

The University of Chicago
The exception, she noted, is when the license goes "to a startup company founded by the faculty inventor who wants to be near the campus."

Examples include Anagen Therapeutics Inc. and Maroon Biotech Corp. Both were founded in 2002 and are based in Chicago. Anagen is developing drugs for androgen and nuclear receptor-related diseases. Maroon is developing surfactant chaperones to restore structure and viability to cells disrupted by physical or chemical trauma.

To help keep startups at home, in 2005 the university established a research park in Skokie, which is a few miles west of Northwestern's main campus in Evanston.

"We have four of our startups there and we'd like them to remain, but we're not going to strangle a company by keeping it in our backyard," said Mukharji. "A number of our companies move to California when the venture money comes in. The VCs want the company to be close, and we don't say no to that."

"The question of whether we suffer from our location is nuanced," said Chicago's Thomas. "On one level, we do somewhat because Silicon Valley and Cambridge, Massachusetts, are loaded with people that have venture or biotech or some form of entrepreneurial experience. Here, you can blow cannonballs and you won't hit a single such person. The tech transfer office here just doesn't have the density of interactions, although that can be overcome with phone and e-mail and getting on planes."

The more subtle issue, said Thomas, is that biotech clusters are loaded with people who "understand the relationship between science and its application. There are inevitably conversations between those folks and investigators. What that means is that there's an influence on how the investigators think. The result is that I think the intellectual capital at a relatively $\$ 234.9$ million in series A rounds, an average of just under $\$ 10$ million, or about two-thirds of what New England companies receive.

"The situation Chicago finds itself in is similar to that of the vast majority of institutions," said Alan Thomas, director of the Office of Technology and Intellectual Property at The University of Chicago. "Stanford and MIT are mutants-they're really the exception and not the mainstream. The question isn't why can't everyone else be like them; it's more like how did they get to be that successful."

Thomas said his office "went through the exercise of sticking pins in a map" to see where the university's discoveries end up. "It almost perfectly matches where the entrepreneurial clusters are. There was a big bunch in New England, a bunch in Northern California, some in Southern California, and some in Research Triangle. There was a reasonable cluster in the Midwest of licensees, but perhaps unsurprisingly most of our stuff ends up in the coastal clusters."

Indeed, of the 14 disclosed deals with established biotech/pharma companies on the University of Chicago's technology transfer website, none has been with companies in the Midwest. Seven of those licenses went to companies on the East Coast-including four in Massachusetts-and three deals were with California companies.

Northwestern does not release the names of its licensees, but Mukharji did tell SciBX that "the large majority of our biotech/pharma licenses are with companies outside of Illinois." isolated institution is not sitting in a bath of people thinking about translational relevance."

Both Northwestern and the University of Chicago have been taking steps to promote their translational discoveries. The latter, for example, recently set up a program in which medicinal chemistry screening specialists from industry interact with faculty. Those sessions, said Thomas, "have been extremely helpful for the faculty to understand some of industry's considerations and for the outsiders to see the early pipeline at the university. We're doing something similar with biologics and devices. They seem to resonate well, and faculty self-select if they're interested."

Similarly, Mukharji said Northwestern holds sessions in which the faculty makes presentations to VCs and angel investors.

On the company side, she said, the university's technology licensing office finds out who's in the space for a given discovery, initiates a dialog with the appropriate companies and provides them with an abstract or summary of the highlights. "If all goes well, there's an option agreement for a short period and then the company decides whether or not to enter a full-blown license agreement," Mukharji said.

\section{Emory: Georgia on my mind}

The pattern at Emory University is like that of Chicago-area institutions-local startups and nonlocal partnerships. Since 2001, Emory 
has started at least 19 biotech companies, with 10 based in Georgia.

The three most recent are all based in Atlanta: AxoTect Inc., BioSequent LLC and Zetra Biologicals LLC. AxoTect is developing calpain inhibitors to treat chemotherapy-induced pain; BioSequent produces copolymers for cardiovascular graft procedures; Zetra is focused on infectious disease vaccines.

As in Chicago, companies can stay in Atlanta in their early years, but they tend to leave as they need more money.

"Most of our startups have proximity to Emory and Atlanta for some time, as they rely on the lab of the professor" whose science underlies the company, said Todd Sherer, associate VP of research and director of Emory's Office of Technology Transfer. "We find that we can initially get deals funded here in Atlanta, but as companies get more mature and into the $\mathrm{B}$ and $\mathrm{C}$ rounds, they relocate."
That was the case with Pharmasset Inc., which was founded in 1998 by four Emory researchers focused on chemistry, pharmacology, virology and biology. The company originally was based near Atlanta, but relocated to Princeton, N.J., in 2005-about a year after it completed a $\$ 40$ million series $\mathrm{D}$ financing. At the time, the infectious disease company said it wanted to be located in a scientific hub and also wanted proximity to partners Roche and Incyte Corp. Roche has operations in Nutley, N.J., whereas Incyte is headquartered in Wilmington, Del.

Overall, Sherer said Emory's startup activity has ebbed since the start of the economic crisis. For the fiscal year that ended Aug. 31, 2008 , the university only formed three startups, down from six in the prior fiscal year.

Licensing also has slowed by about $50 \%$ in fiscal 2008 vs. fiscal 2007. "We definitely have found it harder to do deals," he said. "We

Table 1. Getting started. Selected list of companies that Emory University, Institut National de la Santé et de la Recherche Médicale (INSERM), Max Planck Innovation GmbH, Northwestern University, University of Oxford and The University of Chicago say they have spun out. Money raised from equity/debt unless otherwise noted and may exceed the amounts listed. In certain cases where date of financings were not available, current exchange rates were applied.

\begin{tabular}{|c|c|c|c|c|}
\hline Company & Technology summary & $\begin{array}{c}\text { Year } \\
\text { founded }\end{array}$ & Location & $\$$ raised \\
\hline \multicolumn{5}{|l|}{ Emory University } \\
\hline altiris Therapeutics & $\begin{array}{l}\text { Small molecules against CXC chemokine receptor } 4 \\
\text { (CXCR4) to treat cancer and HIV }\end{array}$ & 2005 & Atlanta, Ga. & $\$ 38.6 \mathrm{M}$ \\
\hline ALVitae Pharmaceuticals Inc. & Diagnostics and therapeutics for cancer & 2005 & San Ramon, Calif. & Not available \\
\hline AxoGen Inc. & $\begin{array}{l}\text { Therapeutic device for peripheral nerve repair and } \\
\text { regeneration }\end{array}$ & 2002 & Alachua, Fla. & $\$ 19.6 \mathrm{M}$ \\
\hline AxoTect Inc. & Calpain inhibitors for chemotherapy-induced pain & 2005 & Atlanta, Ga. & Not available \\
\hline BioSequent LLC & $\begin{array}{l}\text { Elastin-mimetic protein triblock copolymers for use in } \\
\text { cardiovascular grafts }\end{array}$ & 2007 & Atlanta, Ga. & Not available \\
\hline $\begin{array}{l}\text { Cardiovascular Prevention } \\
\text { Diagnostics LLC }\end{array}$ & Diagnostics based on oxidative stress biomarkers & 2003 & Atlanta, Ga. & Not available \\
\hline $\begin{array}{l}\text { Cougar Biotechnology Inc. } \\
\text { (NASDAQ:CGRB) (being acquired } \\
\text { by Johnson \& Johnson (NYSE:JNJ)) }\end{array}$ & Noscapine and noscapine derivatives for cancer & 2003 & Los Angeles, Calif. & $\$ 184.6 \mathrm{M}$ \\
\hline Crystalplex Corp. & $\begin{array}{l}\text { Quantum dots for optoelectronic, security and life- } \\
\text { science applications }\end{array}$ & 2003 & Pittsburgh, Pa. & $\$ 100 \mathrm{~K}$ \\
\hline Curry Pharmaceuticals & $\begin{array}{l}\text { Curcumin-based therapeutics for dermatology, cancer, } \\
\text { inflammation and autoimmune diseases }\end{array}$ & 2003 & $\begin{array}{l}\text { Research Triangle Park, } \\
\text { N.C. }\end{array}$ & Not available \\
\hline GeoVax Labs Inc. & HIV vaccines & 2001 & Atlanta, Ga. & $\$ 740 \mathrm{~K}$ \\
\hline GSH Biomedical Ltd. & Glutathione to prevent influenza infection & 2001 & Liverpool, U.K. & Not available \\
\hline iThemba Pharmaceuticals Pty Ltd. & Antivirals and antibacterials & 2001 & $\begin{array}{l}\text { Mpumalanga, } \\
\text { South Africa }\end{array}$ & $\$ 4 \mathrm{M}$ \\
\hline NeurOp Inc. & $\mathrm{pH}$ sensitive NMDAR antagonists & 2002 & Atlanta, Ga. & $\begin{array}{l}\$ 2.2 \mathrm{M} \text { ( } \$ 500 \mathrm{~K} \text { from angels } \\
\text { via convertible debt; } \$ 1.7 \mathrm{M} \\
\text { in NIH grants) }\end{array}$ \\
\hline RayBiotech Inc. & Protein array and antibody analysis systems & 2002 & Atlanta, Ga. & Not available \\
\hline $\begin{array}{l}\text { Revitus Inc. (merged with } \\
\text { BioVascular Inc. in 2007) }\end{array}$ & $\begin{array}{l}\text { Thrombopoietin antagonists to prevent heart attacks and } \\
\text { stroke }\end{array}$ & 2004 & Portland, Ore. & Not available \\
\hline RFS Pharma LLC & Antivirals for HIV and HCV & 2004 & Tucker, Ga. & $\$ 400 \mathrm{~K}$ in grants \\
\hline SiGen Pharmaceuticals & $\begin{array}{l}\text { Compounds that improve the efficacy of small } \\
\text { interfering RNAs }\end{array}$ & 2006 & San Ramon, Calif. & Undisclosed angels \\
\hline Sla'inte Bioceuticals Inc. & Sphingolipids for cancer and inflammatory diseases & 2002 & Marietta, Ga. & Not available \\
\hline Zetra Biologicals LLC & $\begin{array}{l}\text { Vaccines for pandemic influenza and other infectious } \\
\text { diseases }\end{array}$ & 2007 & Atlanta, Ga. & Undisclosed grants \\
\hline
\end{tabular}




\section{TRANSLATIONAL NOTES}

Table 1. Getting started. (Continued)

\begin{tabular}{l} 
Company \\
\hline INSERM \\
\hline CellVir S.A. \\
\hline DNA Therapeutics S.A. \\
\hline Genoscreen \\
\hline Metagenex \\
\hline Neorphys
\end{tabular}

Neurokin S.A.

Technology summary

Year

founded Location

$\$$ raised

Retrovirals for HIV

2006 Evry, France \$347K

Oligonucleotides to treat cancer

2006 Evry, France

$\$ 4.1 \mathrm{M}$

Functional genomics and proteomics services

2001 Lille, France

$\$ 920 \mathrm{~K}$

Diagnostics that detect rare cells in blood

2001 Paris, France

$\$ 3.7 \mathrm{M}$

Therapeutics for postoperative pain and female sexual

2005 Nimes, France

$\$ 2.9 \mathrm{M}$ dysfunction

Pharmaxon S.A.

Cyclin-dependent kinase inhibitors for stroke and epilepsy

Adhesion molecule modulators for spinal cord injury,

2003 Marseille, France

$\$ 625 \mathrm{~K}$ neurodegenerative disease and glioma

TcL Pharma S.A.

Antibodies to prevent organ transplant rejection

2004 Marseille, France $\quad \$ 611 \mathrm{~K}$

TcLand Expression S.A.

Tests to predict organ transplant rejection

2007 Nantes, France \$833K

TxCell S.A.

Cell therapies for inflammatory diseases

2002 Nantes, France \$12M

Vaxon-Biotech

Cancer vaccines based on cryptic peptides

2001 Sophia Antipolis, France \$29M

Max Planck Innovation

Affectis Pharmaceuticals AG

Therapeutics for psychiatric and inflammatory disorders

Alnylam Pharmaceuticals Inc.

(NASAQ:ALNY)

\begin{tabular}{|c|c|c|c|c|}
\hline AmVac AG & $\begin{array}{l}\text { Immune therapies and vaccines for gynecology, urology } \\
\text { and respiratory diseases }\end{array}$ & 2005 & Zug, Switzerland & Not available \\
\hline amYmed GmbH & Immunoreagents for diagnosing amyloid diseases & 2006 & Martinsried, Germany & Not available \\
\hline Autodisplay Biotech GmbH & Production of biocatalysts and bioanalytical tools & 2008 & Dusseldorf, Germany & Not available \\
\hline $\begin{array}{l}\text { Capsulution NanoScience AG } \\
\text { (merged with Nanodel Technologies } \\
\text { GmbH in 2008) }\end{array}$ & Nanotechnology for drug delivery and diagnostics & 2000 & Berlin, Germany & $\$ 2.8 \mathrm{M}$ \\
\hline Direvo Biotech AG & $\begin{array}{l}\text { Bioengineered enzymes for biorefineries and food and } \\
\text { feed markets (sold biopharmaceuticals business to } \\
\text { Bayer AG (Xetra:BAY) in 2008) }\end{array}$ & 2000 & Cologne, Germany & $\$ 35.4 \mathrm{M}$ \\
\hline IonGate Biosciences GmbH & Membrane measurement tools & 2000 & Frankfurt, Germany & $\$ 8.2 \mathrm{M}$ \\
\hline Jado Technologies GmbH & Small molecules for allergies and infectious diseases & 2001 & Dresden, Germany & $\$ 10.9 \mathrm{M}$ \\
\hline Kinaxo Biotechnologies GmbH & Cellular target profiling services & 2005 & Martinsried, Germany & $\$ 764 \mathrm{~K}$ \\
\hline RNAx GmbH & RNA screens & 2002 & Berlin, Germany & Not available \\
\hline Scienion AG & Microarrays for low-volume liquid handling & 2001 & Dortmund, Germany & $\$ 10.9 \mathrm{M}$ \\
\hline SuppreMol GmbH & $\begin{array}{l}\text { Methods to block autoimmune diseases by inhibiting the } \\
\text { activation of B cells by immune complexes }\end{array}$ & 2002 & Martinsried, Germany & $\$ 24.9 \mathrm{M}$ \\
\hline $\begin{array}{l}\text { U3 Pharma AG (acquired by } \\
\text { Daiichi Sankyo Co. Ltd. } \\
\text { (Tokyo:4568; Osaka:4568) in 2008) }\end{array}$ & Antibodies for cancer & 2001 & Martinsried, Germany & $\$ 53.7 \mathrm{M}$ \\
\hline \multicolumn{5}{|l|}{ Northwestern University } \\
\hline American BioOptics LLC & Diagnostics for colorectal cancer & 2006 & Evanston, Ill. & $>\$ 16 \mathrm{M}$ in grants \\
\hline NanoInk Inc. & $\begin{array}{l}\text { Nanotechnology for life science and semiconductor } \\
\text { industries }\end{array}$ & 2001 & Skokie, Ill. & $>\$ 9 M$ \\
\hline Nanosphere Inc. (NASDAQ:NSPH) & Nanotechnology-based diagnostics & 2000 & Northbrook, Ill. & $\$ 194.7 \mathrm{M}$ \\
\hline Viamet Pharmaceuticals Inc. & $\begin{array}{l}\text { Metalloenzyme inhibitors for infectious diseases and } \\
\text { cancer }\end{array}$ & 2005 & $\begin{array}{l}\text { Research Triangle Park, } \\
\text { N.C. }\end{array}$ & $\$ 6.25 \mathrm{M}$ \\
\hline \multicolumn{5}{|l|}{ University of Oxford } \\
\hline Celleron Therapeutics Ltd. & $\begin{array}{l}\text { CancerNav technology that identifies biomarkers of a } \\
\text { tumor's sensitivity to a specific cancer drug }\end{array}$ & 2005 & Oxford, U.K. & Not available \\
\hline Crysalin Ltd. & $\begin{array}{l}\text { Crysalin lattice nanotechnology for tailored crystal } \\
\text { formation }\end{array}$ & 2007 & Oxford, U.K. & Not available \\
\hline
\end{tabular}




\section{TRANSLATIONAL NOTES}

Table 1. Getting started. (Continued)

\begin{tabular}{|c|c|c|c|c|}
\hline Company & Technology summary & $\begin{array}{c}\text { Year } \\
\text { founded }\end{array}$ & Location & $\$$ raised \\
\hline Cytox Ltd. & Genetic tests for Alzheimer's disease & 2006 & Birmingham, U.K. & Not available \\
\hline Eykona Technologies Ltd. & Imaging technology for advanced wounds & 2007 & Oxford, U.K. & Undisclosed \\
\hline Glycoform Ltd. & $\begin{array}{l}\text { Sugar chemistry and protein glycosylation technology to } \\
\text { produce biosimilars }\end{array}$ & 2002 & Abingdon, U.K. & $\$ 2.8 \mathrm{M}$ \\
\hline g-Nostics & Pharmacogenetic test for smoking cessation products & 2004 & Oxford, U.K. & $\$ 4 \mathrm{M}$ \\
\hline InhibOx Ltd. & Computational drug discovery & 2001 & Oxford, U.K. & Not available \\
\hline Oxford BioDynamics Ltd. & $\begin{array}{l}\text { Chromosomal Confirmation Fingerprinting technology } \\
\text { for detecting aberrant gene expression }\end{array}$ & 2007 & Oxford, U.K. & $\$ 10 \mathrm{M}$ \\
\hline Oxford Biosensors Ltd. & $\begin{array}{l}\text { Multisensor, dry enzyme system for analyte } \\
\text { measurement }\end{array}$ & 2000 & Yarnton, U.K. & Not available \\
\hline Oxford Immunotec Ltd. & Infectious disease diagnostics & 2002 & Oxford, U.K. & $\$ 57.2 \mathrm{M}$ \\
\hline Oxford Nanopore Technologies Ltd. & $\begin{array}{l}\text { Nanopore sequencing technology for label-free, single- } \\
\text { molecule DNA sequencing and molecular sensing }\end{array}$ & 2005 & Kidlington, U.K. & $\$ 19.8 \mathrm{M}$ \\
\hline $\begin{array}{l}\text { Oxford-Emergent Tuberculosis } \\
\text { Consortium Ltd. }\end{array}$ & $\begin{array}{l}\text { Joint venture between University of Oxford and } \\
\text { Emergent BioSolutions Inc. (NYSE:EBS) to develop } \\
\text { MVA85A tuberculosis vaccine }\end{array}$ & 2008 & Oxford, U.K. & Not available \\
\hline Particle Therapeutics Ltd. & Drug delivery and reformulation & 2006 & Oxford, U.K. & Not available \\
\hline Pharminox Ltd. & Small molecules for cancer & 2002 & Oxford, U.K. & $\$ 7 \mathrm{M}$ \\
\hline ReOx Ltd. & $\begin{array}{l}\text { Therapeutics that modulate hypoxia-inducible factor- } \\
\text { related enzymes for cardiovascular diseases }\end{array}$ & 2003 & Oxford, U.K. & Not available \\
\hline RioTech Pharmaceuticals Ltd. & HCV therapeutics & 2003 & London, U.K. & $\$ 1.4 \mathrm{M}$ \\
\hline Summit Corp. plc (LSE:SUMM) & Drug discovery and toxicology services & 2003 & Abingdon, U.K. & $\$ 45.1 \mathrm{M}$ \\
\hline $\begin{array}{l}\text { Surface Therapeutics Ltd. } \\
\text { (acquired by Serentis Inc. in 2007) }\end{array}$ & Therapeutics for inflammatory epithelial diseases & 2004 & Oxford, U.K. & Not available \\
\hline Zyentia Ltd. & Modified human calcitonin for osteoporosis & 2002 & Cambridge, U.K. & $\$ 2.8 \mathrm{M}$ \\
\hline \multicolumn{5}{|l|}{ University of Chicago } \\
\hline Anagen Therapeutics Inc. & $\begin{array}{l}\text { Therapies for androgen and nuclear receptor-related } \\
\text { diseases }\end{array}$ & 2002 & Chicago, Ill. & Not available \\
\hline Maroon Biotech Corp. & $\begin{array}{l}\text { Surfactant chaperones for trauma, spinal cord } \\
\text { compression and malignant hypothermia }\end{array}$ & 2002 & Chicago, Ill. & Not available \\
\hline Midway Pharmaceuticals Inc. & Therapeutics for GI tract diseases & 2005 & Spring House, Pa. & $\$ 500 \mathrm{~K}$ \\
\hline NephRx Corp. & Therapeutics for kidney failure and GI tract diseases & 2001 & Kalamazoo, Mich. & $>\$ 2.2 \mathrm{M}$ \\
\hline
\end{tabular}

really saw a slowdown last fall. My theory is that industry was reacting strongly to the economic conditions and stopped all new in-licensing or dramatically reduced it."

Sherer did say conditions have improved in the past six months, and he expects deal activity in the current fiscal year to be "somewhere between two-thirds and three-quarters of where we were in 2007."

Geographically, Emory technology that is out-licensed to established companies rarely remains in Georgia. Excluding Emory startups, only one of seven disclosed biotech/pharma deals was with a Georgiabased entity-ophthalmic player Alimera Sciences Inc.

In 2007, Alimera received an exclusive worldwide option from the university to license NADPH oxidase inhibitors to treat ophthalmic indications.

"We're a little more agnostic to where deals get done than are state universities, which have more of a local mandate," noted Sherer.

\section{Oxford: keeping it in the kingdom}

In the U.K., the problem isn't getting started, it's getting long-term funding. Since 2005, there have only been 16 series A rounds for U.K. companies. The total raised in those rounds was $\$ 223.9$ million, for an average of $\$ 14$ million.

The University of Oxford technology transfer arm, Isis Innovation Ltd., keeps the vast majority of its spinouts local. In the past decade, Isis set up 62 spinouts, of which about half were in life science.

"All bar two are still located within the Oxford region," said Tom Hockaday, managing director of Isis Innovation. "In some cases they've had an exit and are now part of a more international company. But the good news from our perspective is that in the exits, the acquiring company kept it going in the Oxford region. This shows that the acquirer sees benefits of staying in the area."

Indeed, the area houses more than 140 companies and more than 300,000 square feet of lab space. "It's actually a pretty powerful infrastructure to support the development of biotech companies," Hockaday told SciBX.

He added that Isis has helped its 62 spinouts raise $£ 36$ million ( $\$ 58.9$ 
million) from either seed funds or business angels. "What's much less well served in the country is the series A round of venture capital," he said.

Indeed, since 2005 only one Isis spinout has closed a sizeable venture round-Oxford Nanopore Technologies Ltd., a DNA sequencing and molecular sensing company, raised $£ 10$ million (\$19.8 million) in a private round in 2008 .

Isis' licensing activity tells a more global story. "Of all the licenses we've done, $43 \%$ have been to U.K. companies and $37 \%$ to the U.S.," said Hockaday.

Although Hockaday said Isis is ambivalent about whether it licenses IP or spins it out into a new company, he did note that the first step "is always to speak with the existing market first. This helps see to what extent the existing sector is interested and gives a feel for the scale and value of the technology. We learn a lot from talking to them."

\section{Germany: Planck's platform}

The German experience with early-stage companies is similar to that of the U.K. Indeed, there have been only 12 announced series A rounds in Germany since 2005. The total $\$ 163.1$ million raised averages to $\$ 13.6$ million per round.

One potential reason for this dearth of new venture-backed companies is that the Max Planck Society, one of Germany's main sources of translational science, recently has focused more on licensing than spinouts.

Max Planck Innovation GmbH, the technology transfer arm of Max Planck, has spun off 30-40 biotech companies in the past decade, according to managing director Jörn Erselius. However, many of the spinouts came during 2000-2002, and recent years have seen a decline in new company formation. There were no biotech spinouts in 2007 and only one last year-biocatalyst and tool company Autodisplay Biotech GmbH.

As with University of Oxford, almost all of Max Planck's spinoffs remain local. The most recent exception was in 2005, with the formation of AmVac AG. The immune therapy and vaccine company is based in Switzerland.

In contrast, "the majority of our life science technology licenses were outside Germany" in recent years, noted Erselius.

And for all deals, the message Max Planck kept receiving was that potential partners wanted more fully ripened assets, such as clinicready compounds.

To meet industry's desire for more advanced compounds, Max Planck has been developing infrastructure to take its translational discoveries further down the development path. Over the past year, Max Planck has formed the Lead Discovery Center GmbH and DDC Ventures. ${ }^{1}$ The former is responsible for producing lead molecules against targets discovered by Max Planck researchers, whereas the latter is expected to take those leads through preclinical development.

Max Planck's push for more polished assets has received $€ 20$ million (\$27.2 million) in funding from the German Federal Ministry of Education and Research, and, as a result, Max Planck is keen to keep many of its licenses local.

\section{INSERM: internal outreach}

Similar to Max Planck, science emerging from France's Institut
National de la Santé et de la Recherche Médicale (INSERM) is more likely to be partnered than spun out into a new company.

Augustin Godard, business development manager at INSERM Transfert S.A., INSERM's technology transfer arm, said licenses account for $70-90 \%$ of technology transfer, with spinouts making up the remainder.

About 50\% of the institute's licenses are with French biotech and pharma companies, with the U.S. and Europe accounting for $40 \%$ and $10 \%$, respectively. Most U.S. deals are with companies in the Boston or San Francisco Bay areas, noted Godard.

Unlike many other institutions, Godard said, INSERM has not found it harder to out-license its technology under the current economic conditions. "The big pharmas and biotechs are starting to rediscover academic research to fill their pipelines," he said. "It is true that deals take more time and the bargaining power is not as strong as it used to be."

Since 2001, about a dozen biotech companies have spun out with seed backing from INSERM Transfert. All of the spinouts are located in France, but only two-TxCell S.A. and TcLand Expression S.A.have raised more than $\$ 5$ million.

TxCell, a developer of cell therapies for inflammatory diseases, was founded in 2001 and has raised a total of $\$ 29$ million. TcLand is focused on tests to predict organ transplant rejection. The company was founded in 2002 and has raised $\$ 12$ million.

Godard said that although seed money is readily available in France, "the next step-where you need \$5-\$10 million-is where we face more difficulties versus the U.S."

Another challenge, according to Godard, is prodding researchers to view their discoveries with an eye toward translation.

"A big part of our job is educating researchers to make them more amenable to technology transfer," said Godard.

To that end, INSERM Transfert runs training and education sessions for faculty to "take case studies and explain the value of creating a spinoff or out-licensing," he said. "Some of our centers also have R\&D days where they invite biotech and pharma companies to participate."

Edelson, S. SciBX 2(25); doi:10.1038/scibx.2009.994

Published online June 25, 2009

\section{REFERENCES}

1. Edelson, S. SciBX 2(20); doi:10.1038/scibx.2009.815

\section{COMPANIES AND INSTITUTIONS MENTIONED}

Alimera Sciences Inc., Alpharetta, Ga.

American BioOptics LLC, Evanston, III.

AmVac AG, Zug, Switzerland

Anagen Therapeutics Inc., Chicago, III.

The Association of University Technology Managers, Deerfield, III. Autodisplay Biotech GmbH, Dusseldorf, Germany

AxoTect Inc., Atlanta, Ga.

BioSequent LLC, Atlanta, Ga.

Boston University, Boston, Mass.

DDC Ventures, Munich, Germany

Emory University, Atlanta, Ga.

German Federal Ministry of Education and Research, Bonn, Germany

Ikaria Holdings Inc., Clinton, N.J.

Incyte Corp. (NASDAQ:INCY), Wilmington, Del.

INSERM Transfert S.A., Paris, France

Institut National de la Santé et de la Recherche Médicale, Paris, France

Isis Innovation Ltd., Oxford, U.K.

Lead Discovery Center GmbH, Dortmund, Germany

Maroon Biotech Corp., Chicago, III. 


\section{TRANSLATIONAL NOTES}

Massachusetts Institute of Technology, Cambridge, Mass. Max Planck Innovation GmbH, Munich, Germany

Max Planck Society, Munich, Germany

Northwestern University, Evanston, III.

Oxford Nanopore Technologies Ltd., Kidlington, U.K.

Pharmasset Inc., Princeton, N.J.

Roche (SIX:ROG), Basel, Switzerland
TcLand Expression S.A., Nantes, France

TxCell S.A., Sophia Antipolis, France

The University of Chicago, Chicago, III.

University of Oxford, Oxford, U.K.

Viamet Pharmaceuticals Inc., Research Triangle Park, N.C.

Xanodyne Pharmaceuticals Inc., Newport, Ky.

Zetra Biologicals LLC, Atlanta, Ga. 